\title{
Rhizophora stylosa prop roots even when damaged prevent wood-boring teredinids from toppling the trees
}

\author{
Ian W. Hendy $\cdot$ Simon M. Cragg
}

Received: 1 August 2016/Revised: 11 January 2017/ Accepted: 25 January 2017

(C) The Author(s) 2017. This article is published with open access at Springerlink.com

\begin{abstract}
This study examines the ability of live Rhizophora stylosa prop roots to heal damaged tissues and defend against herbivorous attack from teredinids in three mangrove forests. Sites were chosen because damaged roots and teredinid activity were frequent. Responses of $81 R$. stylosa roots to three levels of experimental damage were investigated: superficial, moderate and severe. Tannin intensity post damage was analysed using ImageJ. Losses of tissue and numbers of teredinid tunnels within damaged roots among sites were not significant in magnitude. Tissue regrowth varied significantly among roots; moderately damaged roots had an over compensatory regrowth of tissue. Yet, few roots with severe damage demonstrated the same level of excessive tissue regrowth, and many roots lost tissue to necrosis and teredinid attack. Superficially damaged roots did not succumb to teredinid attack. Rhizophora stylosa roots are able to defend against teredinid larval settlement by production of tannins in damaged cortex tissue and by an over compensatory regrowth. This study highlights the resilience and ability of mangroves to heal damaged
\end{abstract}

Guest editors: K. W. Krauss, I. C. Feller, D. A. Friess \& R. R. Lewis III / Causes and Consequences of Mangrove Ecosystem Responses to an Ever-Changing Climate

I. W. Hendy $(\bowtie) \cdot$ S. M. Cragg

Institute of Marine Sciences, University of Portsmouth,

Ferry Road, Portsmouth PO4 9LY, UK

e-mail: ian.hendy@port.ac.uk roots and defend against woodborers. But, when losses of tissues expose the vascular cylinder, teredinid larvae will settle and tunnel into the root. The roots are then open to infection, and cell necrosis.

Keywords Mangroves · Herbivory · Tissue damage · Root anatomy $\cdot$ Plant stress $\cdot$ Teredinidae $\cdot$ Indonesia

\section{Introduction}

In mangrove forests, trees are attacked by both terrestrial and marine animals (Ellison \& Farnsworth, 1996; Feller, 2002). Mangrove wood herbivores range from insects such as beetles (Perry, 1988; Feller \& Mathis, 1997) to wood-boring aquatic molluscs (Teredinidae) (Robertson \& Daniel, 1989). Mangroves are also subject to tunnelling by non-herbivorous aquatic wood-boring isopods (sphaeromatidae), where principally the mangrove prop and aerial roots are attacked and damaged (Svavarsson et al., 2002).

Damage to prop roots may also occur from physical actions such as abrasion (Gill \& Tomlinson, 1977), or by falling branches from the canopy. Debris brought in by the tides (Lee et al., 2014) and extreme storm events may also damage mangrove roots (McIvor et al., 2013; Jusoff, 2013), which are predicted to increase (Bhatt \& Kathiresan, 2012). Anthropogenic activities will also damage prop roots. Artisanal fishers damage many prop roots from harvesting oysters by 
hacking the bivalves off the roots using machetes (Crow \& Carney, 2013).

Studies of prop-root damage from wood-boring animals are primarily focussed upon sphaeromid isopods (Perry, 1988). In Costa Rica, the destructive effect of the sphaeromid, Sphaeroma peruvianum Richardson, 1910 on live mangrove root tissues can reduce the growth rates of Rhizophora mangle L. aerial prop roots by $50 \%$ (Perry, 1988). Trees affected by isopods may suffer lower performance as photosynthesis, gaseous exchange and nutrient uptake would be reduced compared to uneaten trees. The total effect of minor damage can therefore negatively affect trees by diverting energy to repairing the damage (Brooks \& Bell, 2002), compromising root and tree fitness. However, it is thought that sphaeromids are unable to burrow into older developed roots that reach the substratum due to the development of woody tissue in the older roots (Perry, 1988). The development of woody tissue may be an attractive habitat for larval teredinids to settle upon, but teredinids predominantly process dead wood in the mid-to-low intertidal (Filho et al., 2008; Hendy et al., 2013). Increased tidal inundation may then enhance the breakdown of damaged mangrove roots because densities of wood borers become more numerous with longer immersion (Robertson \& Daniel, 1989; Svavarsson et al., 2002).

Some trees are protected from herbivorous attack by their chemical and structural anti-herbivore defence mechanisms (Turner, 1976; Brooks \& Bell, 2002). Plants are able to survive in environments where herbivores are common due to their ability to resist or recover from repeated herbivory (Brooks \& Bell, 2002; Hanley et al., 2007). To combat attack, some plants release tannins (Bloch, 1952; Alongi, 1987). However, it is beneficial for the plant to produce these chemical compounds only when they are required as herbivore attack is random and variable (Hol et al., 2004). The energy required to produce tannins can be costly (Agrawal et al., 1999; Karban et al., 1997). Thus, particular mangrove trees may express resistance only when it is needed to reduce energetic cost into producing the tannins.

Energy expenditure may eventually lead to a decrease in fitness. The loss of fitness may be due to increased energy investments and greater use of resources (Agrawal, 1999). Conversely, herbivory may be beneficial (Paige \& Whitham, 1987; Paige,
1992). Herbivory on plants elicits a physiological response that can create an over compensation (excess) regrowth of tissue (Lennartsson et al., 1998). Increased plant growth may ultimately achieve greater fitness (Paige \& Whitham, 1987).

There are few reports of teredinids attacking live Rhizophora prop roots (Roonwal, 1954, see Fig. 1). It is thought that larval teredinids are unable to infest living trees (Rimmer et al., 1983; Kohlmeyer et al., 1995) as the bark is tannin-rich (Alongi, 1987; Borges et al., 2008). Teredinids are the major detritivores in mangrove forests that have high levels of dead wood, and they mechanically break down the wood (Robertson, 1990; Kohlmeyer et al., 1995). However, teredinid larval settlement may occur only after the bark has deteriorated (Kohlmeyer et al., 1995) and the tannins have leached away (Borges et al., 2008). The colonised wood may take anywhere from 2 to 15 years to completely break down (Robertson \& Daniel, 1989; Kohlmeyer et al., 1995). Eventually, the broken-down woody fragments, teredinid faeces and teredinid biomass may be consumed by marine organisms in adjacent ecosystems (Robertson \& Daniel, 1989). This means that wood borers may benefit mangrove ecosystems by breaking down dead wood, even though they do cause damage to some living tissues (Barkati \& Tirmizi, 1991).

Plants also express resistance to herbivory via strategies labelled as tolerance mechanisms (Paige, 1999; Brooks \& Bell, 2002), defined as tissue repair and regrowth after exposure from stress. Tissue regeneration reduces the risk from potential infection (Wier et al., 1996). Plants respond to damage and infection by compartmentalising the affected area, reducing the spread of infection to healthy tissues (Bloch, 1952). Compartmentalising sets boundaries that resist the spread of the invading microorganisms (Shigo, 1985). Mangrove plants may likely use the tolerance strategy against damage or stress (Brooks \& Bell, 2002), as many other angiosperms have evolved this response to combat herbivore attack (Strauss \& Agrawal, 1999). Mangroves may also be particularly resilient to stress because of the nature of the environment. Diurnal changes of salinity, temperature and tidal inundation can be particularly stressful for mangroves (Tomascik et al., 1997).

This study aimed to determine why Rhizophora stylosa Griff trees were not toppled by wood boring teredinids by assessing the level of damage required to 

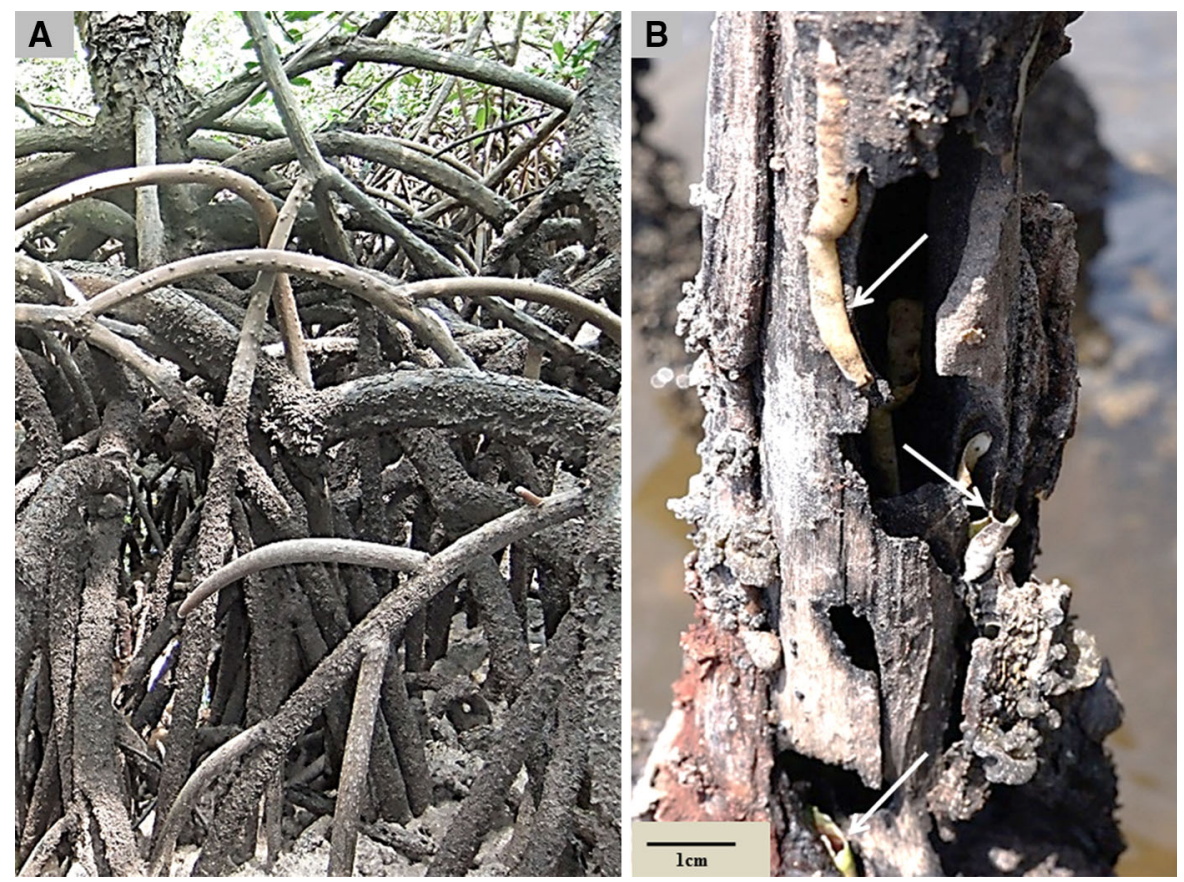

Fig. 1 Rhizophora stylosa prop roots. A undamaged healthy prop roots-a typical view of roots demonstrating no obvious evidence of damage to their periderm (outer layer), and $\mathbf{B}$ a damaged root with teredinid tunnels within the vascular cylinder indicated by arrows

expose roots to teredinid colonisation. We also aimed to assess the regenerative capabilities of mangrove roots under different levels of damage. This work tested the prediction that after 1 year $R$. stylosa roots with: (1) superficial levels of damage (removal of the outer bark, the periderm) will not be attacked by teredinids and will make a full recovery; (2) moderate levels of damage (removal of the cortex) will elicit an over compensatory level of tissue regrowth; and (3) severe levels of damage (removal of the inner radial wall of the vascular cylinder) will die due to a high level of stress.

Rhizophora stylosa prop roots were inspected for damage to determine the level required for teredinid activity. To assess the frequency of different levels of damage, roots were counted in the mangrove forests. The levels of damage upon the prop roots were replicated experimentally on non-damaged prop roots to determine which of the prop-root surfaces are colonisable by teredinids. The protective layers of the roots, the periderm, cortex and vascular cylinder were removed to measure the ability of roots to recover. The extent of infestation by teredinids was quantified. This work was carried out in three sites in East Sulawesi, Indonesia. The sites were chosen because damaged roots were frequent and teredinid activity was also common.

\section{Materials and methods}

Root scar experiment

The experiments took place in three intertidal $R$. stylosa-dominated mangrove forests in the Tukang Besi archipelago, Wakatobi Marine Park, East Sulawesi, Indonesia (see Cragg \& Hendy, 2010 for site details). Six plots measuring $10 \mathrm{~m} \times 10 \mathrm{~m}$ were designated to estimate the number of naturally occurring damaged prop roots in the mangrove forests. Rhizophora stylosa prop roots in six plots measuring $10 \mathrm{~m} \times 10 \mathrm{~m}$ were accessed for damage to determine the level required for teredinid recruitment. In each mangrove forest, three plots measuring $10 \mathrm{~m} \times 10 \mathrm{~m}$ were designated for the experimental damage. Tidal immersion ranged between 18 and $19 \mathrm{~h}$ per day to ensure access to experimentally damaged roots by teredinid larvae. The experimental damage consisted of one of three surgical treatments with increasing severity upon individual roots. Each treatment was 
conducted no more than $20 \mathrm{~cm}$ from the substratum. Within each plot, each treatment was conducted on three individual roots totalling nine roots per plot and 27 roots per site. Within all the sites, a total of 81 roots were used.

The first surgical treatment (superficial) consisted of removal of the outermost layer of the bark, the periderm (Fig. 2A). The second treatment (moderate) consisted of additionally removing the cortex (Fig. 2B), exposing the central vascular cylinder (or stele). The third treatment (severe) consisted of additionally removing the inner radial wall of the vascular cylinder, exposing the inner pith (Fig. 2C).
All surgical treatments were cut into live roots using a diver's knife, and each root scar measured $4 \mathrm{~cm}$ across by $10 \mathrm{~cm}$ along the length of the root. All root circumferences and scar depths were measured before and during a 12-month period using a tape measure and callipers.

Digital images were taken of each treated root over 12 months. The level of tannin content based on colour intensity on each root over a short term of 0 to 45 days was estimated using the digital analysis package ImageJ Version 1.46r. ImageJ uses a red, green and blue (RGB) colour scale. Light is emitted and displayed by the intensity at which these colours
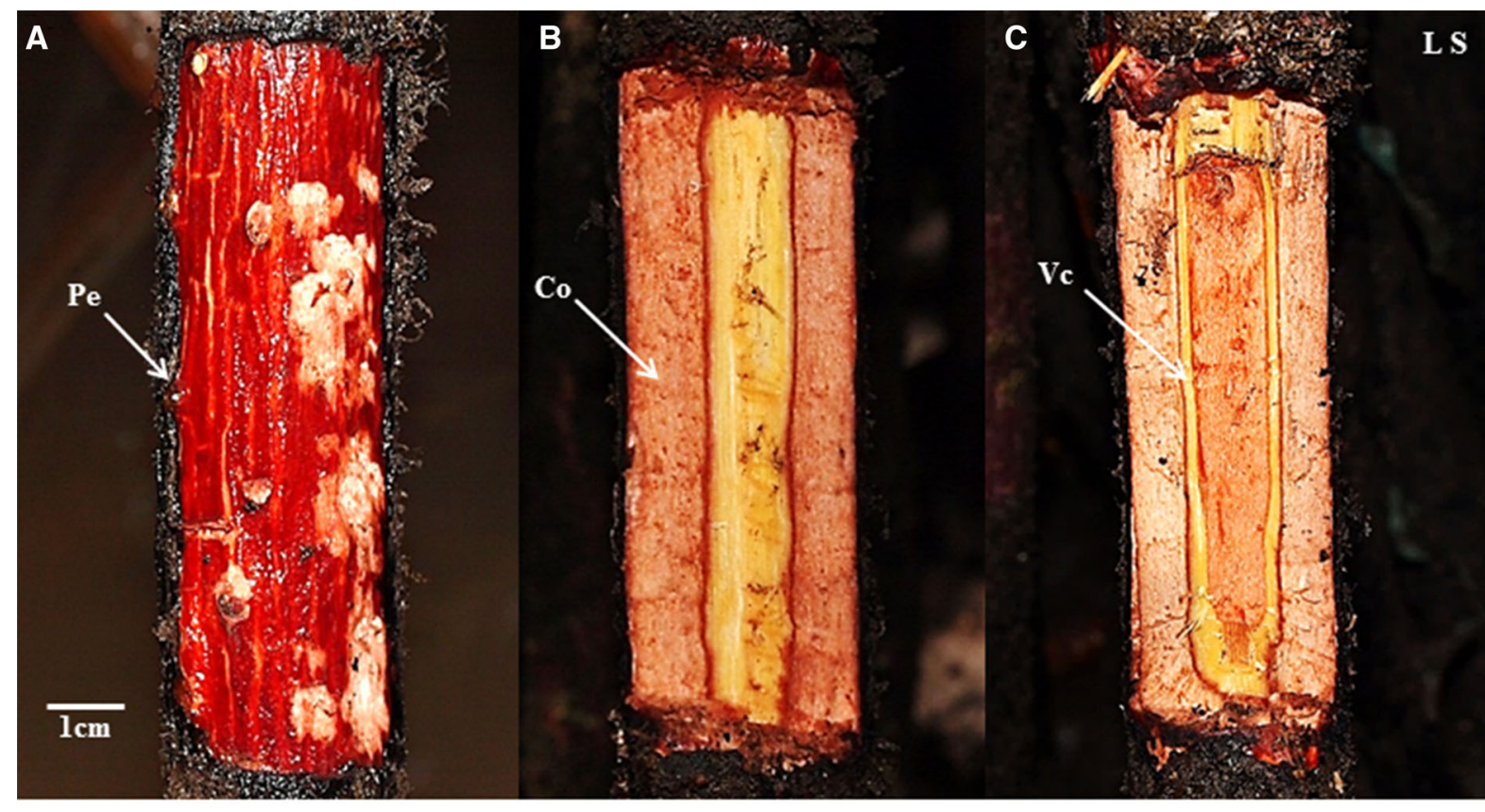

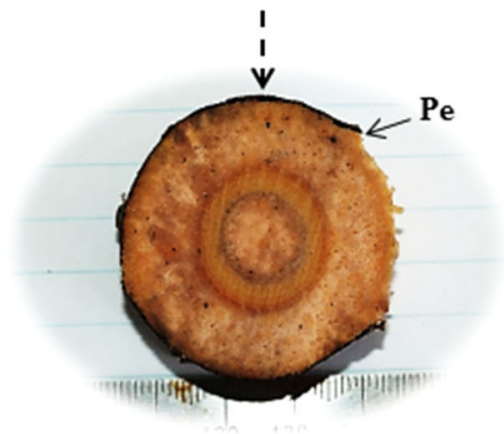

superficial

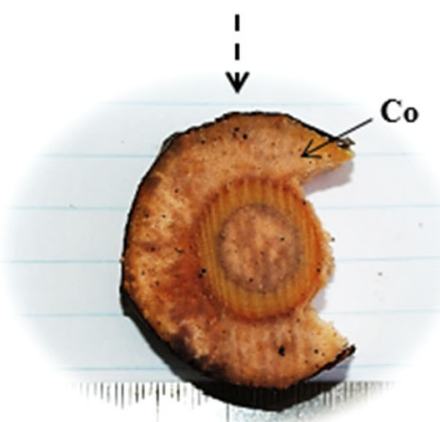

moderate

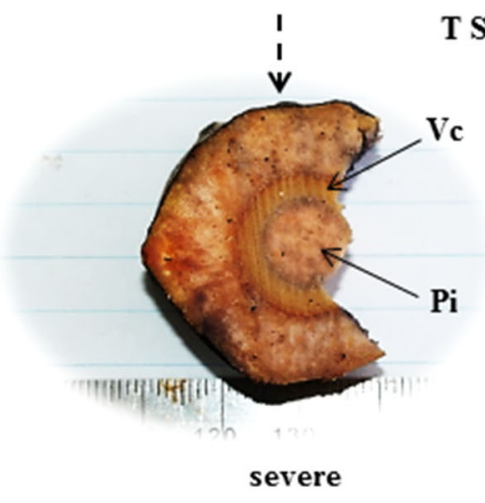

cylinder, and $\mathbf{C}$ removal of the vascular cylinder, (severe damage). $P e$ periderm, Co cortex, $V c$ vascular cylinder, $P i$ pith, $L s$ lateral section, $T s$ transverse section
T S
Fig. 2 Lateral view and transverse sections of three treatments of roots characterised by different levels of damage. A The removal of the periderm layer (superficial damage), B removal of the cortex tissue (moderate damage) exposing the vascular 
are projected. To estimate tannin content, we focussed on red light intensity in each image. ImageJ specifies the intensity of red as an integer between 0 and 255. A colour with red set to 0 specifies the absence of colour and emits no red light. A colour with red set to 255 will appear bright red, or fully saturated with colour. Previous studies have successfully used digital analysis to predict tannin content based on the colour of the image. A strong relationship between colour and tannin content was found (Sedghi et al., 2012).

Root analysis after 12 months

Treatments on 24 of the experimentally damaged roots were cut transversely into sections after 12 months. For each of the levels of damage, eight roots were used. For the superficially damaged roots, 40 sections were cut. For the moderately damaged roots, 36 sections were cut; and for the severely damaged roots, 35 sections were cut. If present, all teredinid tunnels in each section were counted. Sections were inspected for evidence of necrotic cellular damage and then measured to calculate the area of cellular regrowth or loss using ImageTool Version 3.00 (The University of Texas Health Science Centre at San Antonio).

\section{Data analysis}

\section{Live roots}

Differences of colour intensities used as a proxy for tannin content between surgical treatments over time were examined using a General Linear Model (GLM) with time and treatment as factors. Differences of root tissue regrowth after 12 months exposed to the surgical treatments among the three mangrove localities were examined also using a GLM, with site and treatment as factors. A Fisher's exact test was used to test for differences between live and dead roots. Percentage data were normalised using arcsine transformation.

\section{Root section analysis}

Differences of numbers of teredinid tunnels in sections exposed to the surgical treatments among the three mangrove localities were examined using PERMANOVA in Bray-Curtis matrices and post hoc pairwise tests. Values of percentage surface area of tissue regrowth and loss, and the number of teredinid tunnels were tested for differences using Box Plots. A Chi square test was used to examine differences between sections and the number of teredinid tunnels after 12 months. A Fisher's exact test with a post hoc pairwise test was used to test for differences between sections with or without lateral outgrowth of new vascular tissue after 12 months.

All statistical analyses were performed using MINITAB (MINITAB Inc, version 13.20) and PRIMER 6.1 (PrimerE Ltd: Plymouth Routines in Multivariate Ecological Research).

\section{Results}

Naturally occurring damaged prop roots

In the study site, many roots were damaged either by use of tools during firewood collection or by physical abrasion. Of all the roots that were inspected, 20.6\% had been damaged. To add, many undamaged roots showed signs of full wound healing and recovery. Per hectare, there were $950 \pm 216$ (mean \pm SE) roots with damage equivalent to the "superficial" category used in this study, $1033 \pm 281$ (mean \pm SE) with "moderate" damage and $1683 \pm 343$ (mean \pm SE) with "severe" damage. The most prevalent level of damage was severe damage, which is a measure of unhealable damage (PERMANOVA, $F_{2,17}=93$, $P \leq 0.001)$.

Short-term colour intensity (tannin production) on experimentally damaged roots

The cortex of the root took on a strong red colouration after being experimentally damaged. Colour changes on roots with superficial damage occurred within $30 \mathrm{~min}$. Changes on moderately and severely damaged roots were more rapid and conspicuous. No colour changes were observed with the pith tissues protected by the vascular cylinder.

No significant differences in red intensity were detected among the sites (GLM, $F_{2,932}=3.2$, $P \geq 0.05)$. However, intensity declined over time in all three levels of damage and was significantly lower on roots subject to superficial damage than on the more severely damaged roots (GLM, $F_{2,932}=79.8$, 
$P \leq 0.001$ ), and time (Fig. 3, GLM, $F_{6,932}=272.7$, $P \leq 0.001$.

Long-term tissue regrowth and wound healing

After 12 months, no differences of tissue loss and regrowth were detected between the three mangrove localities (GLM, $F_{2,41}=0.6, P \geq 0.05$ ). However, significant differences were found with tissue regrowth among the root treatments (GLM, $\left.F_{2,41}=12.6, P \leq 0.001\right)$. The greatest amount of tissue regrowth was found in the moderately damaged roots (PERMANOVA, $F_{2,108}=8.1, \quad P \leq 0.001$ ). More than $95 \%$ of roots exposed to superficial damage had made a complete recovery. Tissue regrowth was minimal with an increase of $3 \% \pm 0.3 \%$ of the original circumference before surgery. No roots died when exposed to this level of damage (Fig. 4). Tissue regrowth from roots exposed to moderate levels of damage was significantly more compared to the regrowth measured from superficially or severely damaged roots (Fig. 4, PERMANOVA pairwise, $P \leq 0.05$ and $\leq 0.001$, respectively). Almost $80 \%$ of moderately damaged roots had made a full recovery. Fifty-seven percent of those roots exceeded their initial size before surgery by $13 \pm 2.4 \%$. The greatest percentage of tissue regrowth measured on a moderately damaged root was $27.3 \%$ greater in circumference compared to its original size. Zero percent, 15 and $8 \%$ of the roots exposed to superficial, moderate and severe levels of damage (respectively) died. Moderately and severely damaged roots had a significantly greater mortality compared with superficial roots (Fisher's exact test, $P \leq 0.001$ ). No difference of mortality was found between the moderately and severely damaged roots (Fisher's Pairwise Comparison). Many roots exposed to moderate and severe levels of damage had necrotic cell damage. Sixty-six percent of the roots exposed to a severe level of damage made a full recovery. Sixty-one percent of those roots had exceeded their initial circumference with an increase of $9 \pm 2 \%$ before surgery. The greatest percentage of tissue regrowth was $21 \%$ greater in circumference compared to its original size. Root tissue loss was also great, with $-31 \pm 13 \%$ loss of the original circumference (Fig. 4).

\section{Root section analysis}

Losses of root tissue (percentage of $\mathrm{cm}^{2}$ ) were greatest in sections cut from severely damaged roots. But regrowth was greatest in sections cut from moderately

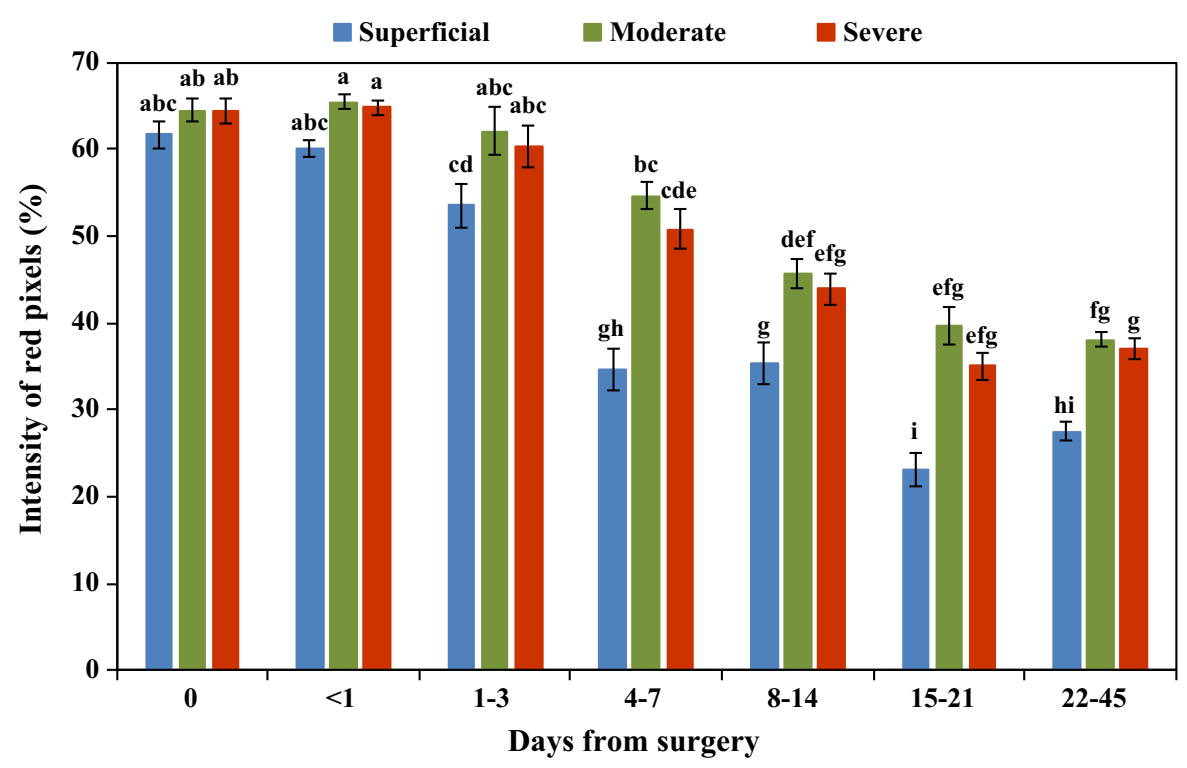

Fig. 3 The percentage of red pixel intensity used as a proxy for tannin production from each damaged root (mean $\pm \mathrm{SE}$, $n=81$ ). Time intervals with significantly different colour intensities are shown by different letters. Asterisks denote when intensity was significantly less in superficially damaged roots (GLM ANOVA with time period and severity of treatments as fixed factors, with Tukey's post hoc pairwise comparisons) 
Fig. 4 Rhizophora stylosa root tissue recovery and loss after 12 months exposure to the three levels of root damage. $x$-axis $=$ percent of root circumference removed, $y$-axis $=$ percent of root circumference recovery after 12 months. Note on the $y$-axis, $100 \%=$ the original root circumference before damage

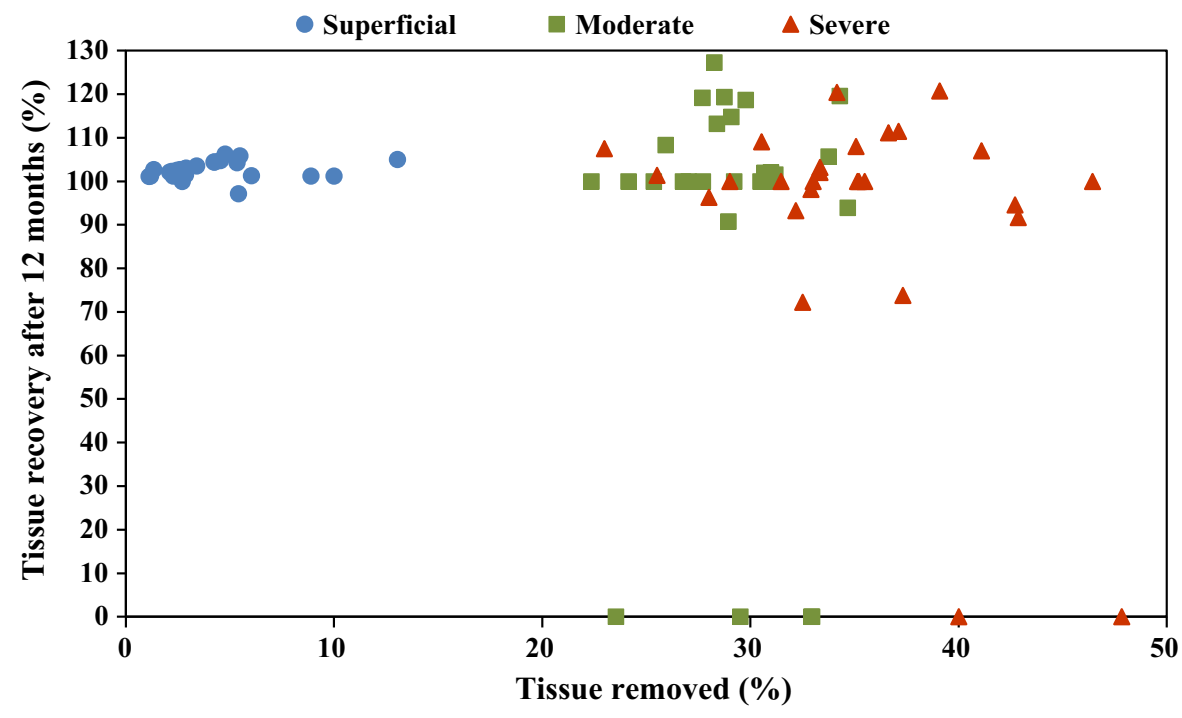

damaged roots. Sections cut from superficially damaged roots had almost no measurable changes.

No differences were found with the number of teredinid tunnels in sections among the three mangrove localities (PERMANOVA, $F_{2,108}=1.1$, $P \geq 0.05)$. However, significant differences were found with the number of teredinid tunnels in sections among different surgical treatments (PERMANOVA, $\left.F_{2,108}=4.5, P \leq 0.001\right)$. A greater number of teredinid tunnels were found when the vascular cylinder of the roots had been removed compared with the roots without exposed pith (Chi squared, $P \leq 0.001$ ). No teredinid tunnels were recorded within the superficially damaged sections (Fig. 5). The analyses of the sections revealed that of the moderately damaged roots, two roots out of 81 roots were colonised by teredinids. Twelve percent of the severely damaged roots were attacked by teredinids, and sections cut from severely damaged roots had between three and 10 teredinid tunnels.

Lateral out-growths of vascular tissue were found growing from the vascular cylinder, but only in moderately and severely damaged roots. Almost $75 \%$ and $36 \%$ of all moderately and severely damaged sections, respectively, had lateral out-growths from the cylindrical vascular tissue.
Fig. 5 Box plot analysis of the roots exposed to the three surgeries. The number of teredinid tunnels within sections exposed to superficial, moderate and severely damaged roots. The boundaries of the boxes indicate the $1 \mathrm{st}$ and $3 \mathrm{rd}$ quartiles. The line within the box marks the median. Outliers are marked as asterisks

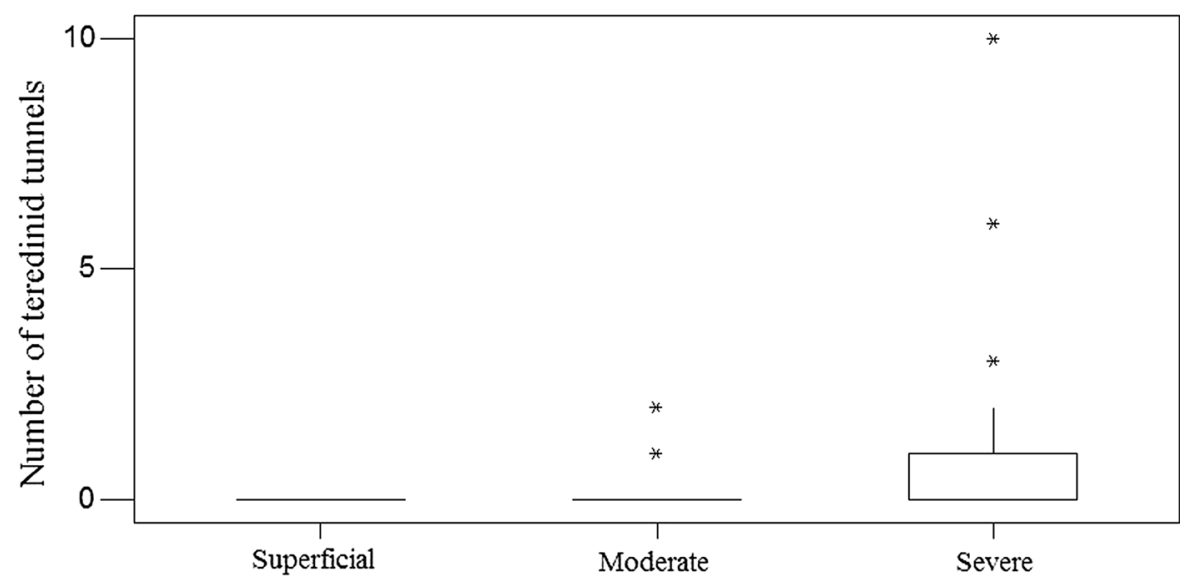




\section{Discussion}

Plant response to experimental damage

The superficially damaged $R$. stylosa prop roots did not respond with excess regrowth of tissues, and shipworms were unable to settle upon the exposed cortex. The parenchyma in the cortex contains numerous tanniniferous cells (Gill \& Tomlinson, 1971), and the tannins these generate may prevent the herbivores from attacking (Feller, 2002). Many roots subjected to experimental damage to the treatments became discoloured and black on the damaged areas. This may have been caused by the large amount of tannins present in the roots (Suh et al., 2014). Tannins undergo oxidation and oxidative darkening produces red, brown and black pigments in the presence of moisture (Nemeth et al., 2013). The blackening of the wounds in the roots is due to the formation of a tannin-ferric iron complex, which counteracts potential toxicity to the roots via oxidation (Kimura \& Wada, 1989).

When the woody vascular cylinder was exposed by the two more radical treatments, the plant became vulnerable to teredinid attack. The vascular cylinder is the water-carrying component (Gill \& Tomlinson, 1971), and the inner limit of the cortex is tannin-free (Gill \& Tomlinson, 1971). The absence of tannins means there was no chemical defence against teredinid larval settlement. In addition, exposure of the woody tissues may induce settlement behaviour, while the spongy cortex layer may not provide the necessary settlement cues. This level of damage allowed settlement for teredinids, rendering the root vulnerable to tissue and water loss, and the root may then die.

Many moderately damaged roots had a remarkable over compensation of tissue regrowth when compared with superficially and severely damaged roots. The wound response of a mangrove is increased by the level of injury. This over compensation is an example of the tolerance mechanism (Brooks \& Bell, 2002), highlighting the resilience of mangroves. Parenchyma cells have the ability to change when stressed and, after tissue damage, may alter the cell physiology and regulate cell growth (Bloch, 1952). Parenchyma cell differentiation may change from generation of parenchyma to generation of cork and sclerenchyma cells (Bloch, 1952;
Wier et al., 1996). Wound-initiated tissue regrowth, also known as wound periderm, compartmentalises wounds and may prevent the spread of potential pathogens to healthy plant tissues (Wier et al., 1996). Plants subject to herbivory may outperform uneaten plants, and plants with an over compensatory level of tissue regrowth produce greater numbers of seeds when compared with uneaten conspecifics (Paige, 1992).

A lower amount of energy is required by the plant to repair superficially damaged tissues than that needed to compensate for moderate or severe damage. The stress imposed to the plant by the increased energy requirement may also be magnified by the stress imposed by teredinid tunnelling. Not all roots were tolerant to the removal of tissues. This may be due to the variation and frequency of teredinid attack coupled with the severity of damage imposed upon each root. Many roots with exposed pith contained teredinid tunnels and had necrotic tissue damage, and some of the damaged root areas were completely lost. It is not uncommon for trees to shed dead or damaged areas. Shedding prevents possible risk of decay extending into the healthy tissues (Mattheck \& Breloer, 1994).

The variation of tissue loss and regrowth between the different surgeries may be due to the degree of stress tolerance of each root. The degree of tolerance can be expressed as compensation to the plants ability to tolerate herbivore attack (Strauss \& Agrawal, 1999), or stress. There are many extrinsic and intrinsic factors for which the plant needs to compensate within each forest, e.g. frequency of herbivore attack and chemical defence investment (Brooks \& Bell, 2002). Thus, energy investment for wound healing leading to a full recovery varies with locality.

Roots exposed to moderate and severe levels of damage had lateral out-growths of new vascular tissue extending from the vascular cylinder. When tissue patterns arise that differ from the norm, or when a lack of pattern is encountered, the cellular regrowth can be classified as atypical (Bloch, 1952). Other authors have reported the same outgrowth of vascular tissue in $R$. stylosa prop roots. Wier et al. (1996) found proliferations of vascular tissue at the cut ends of the vascular cylinder. As renewed cortex grows over the damaged area, a new formation of the vascular cylinder is produced that appears to grow into the 
new cortex tissue. The growth of the new vascular tissues may provide some structural rigidity for the new cortex. This adaptation may be induced by over compensation of the tolerance mechanism (Haukioja \& Koricheva, 2000; Brooks \& Bell, 2002). The damaged area produces an increase of parenchyma cells, and the new outgrowth of non-radial vascular tissue may offer structural rigidity for the increased mass of cortex tissues. In addition, a constituent component of the cortex tissue is suberin. Mechanical wounding of plant tissues activates genes that induce the production of the enzyme phenylalanine ammonia lyase that assists the production of suberin (Karban \& Myers, 1989; Doorn \& Cruz, 2000). An increase of suberin helps with parasite resistance and provides immunity to further infection in the damaged tissues (Karban \& Myers, 1989; Franke \& Schreiber, 2007). Thus, due to increases of suberin, the plants defence against infection and overall fitness may have been enhanced.

Factors in the plant's environment such as salinity and immersion time can also affect its tolerance to herbivory (Strauss \& Agrawal, 1999). Experiments within the three sites were conducted in areas of each forest where teredinid populations thrive in areas of prolonged tidal immersion. Coupled with prolonged immersion, with greater root damage, the level of teredinid tunnelling increased. The rapid recruitment of teredinids found in severely damaged roots may have been facilitated by the removal of the cortex layer that protects the inner vascular cylinder. The vascular cylinder is tannin-free (Gill \& Tomlinson, 1971), making teredinid settlement possible (Turner, 1976). Therefore, tissue loss after one year within the severely damaged roots went beyond the original scaring. Thus, root fitness was compromised. This was also apparent with naturally occurring severely damaged roots, as evidenced by the many teredinid tunnels.

The morphological and physiological resilience of mangrove trees enhances their survival in marine habitats. The regenerative abilities of $R$. stylosa prop roots and the plant's fitness are dependent upon the level of damage imposed to the tissues, coupled with extrinsic factors such as intensity of herbivory. Indeed, there were a large number of naturally damaged roots in the mangrove forests in this study, and many of those roots showed signs of complete recovery. However, those roots with teredinid tunnels were either necrotic or dead in a similar way to that observed in the experimentally severely damaged roots.

Herbivorous attack from sphaeromids and teredinids is different within mangroves. Sphaeromids may benefit the plant by inducing increases of lateral out-branching of new aerial roots (Ribi, 1982). However, studies have shown that the cumulative effect of localised isopod borer damage can scale up to negatively affect the whole tree (Perry, 1988; Brooks \& Bell, 2002). Mangroves with many isopod burrows have significantly fewer propagules, ground roots and pneumatophores when compared with non-burrowed conspecifics (Davidson et al., 2014). However, teredinids are the only borers able to penetrate the thicker woody tissue. The effect of teredinids within the root will result in a greater loss of tissues, but only when the level of damage has compromised the vascular cylinder. Root death may generate woody detritus within the mangrove forests. The activity of the teredinids within woody debris creates many tunnels, which when vacant may provide niches for many animals (Cragg \& Hendy, 2010; Hendy et al., 2013).

This study demonstrates the remarkable ability of mangroves to combat herbivorous activity by the bark barrier, by the production of tannins in damaged cortex tissue and/or by an over compensatory regrowth of tissue. But when the vascular cylinder is accessible, teredinid larvae can settle and begin tunnelling into the live roots. The roots are then open to infection, and cell necrosis will ensue. However, necrotic regions tend to become isolated from the rest of the tree, so that the stability of the tree itself is not significantly compromised. These data demonstrate that $R$. stylosa prop roots are able to defend against teredinid larval settlement when exposed to superficial damage, and prop roots are able to produce an over compensatory level of tissue regrowth with moderate damage increasing root fitness. Yet, when the loss of tissues penetrates the tannin-free vascular cylinder normally protected by the cortex layer, teredinid larvae are able to settle and tunnel into the prop root. 


\section{Summary diagram}

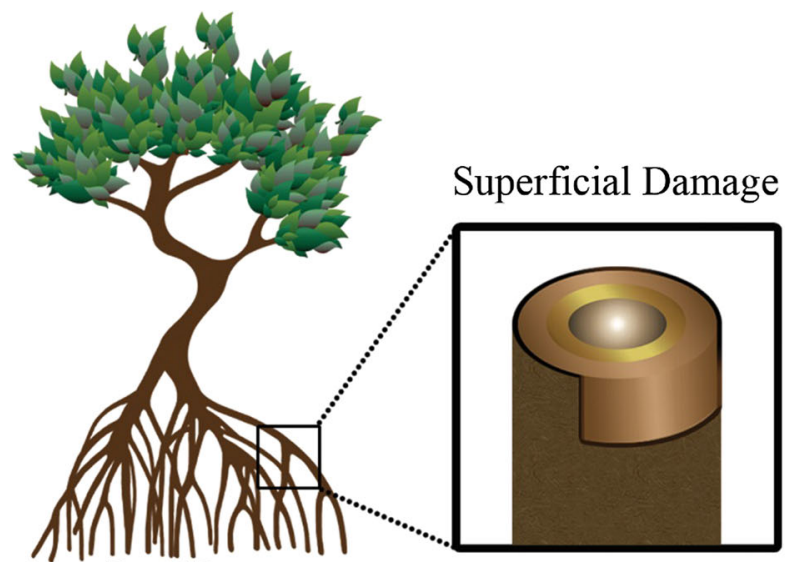

Direct Defence

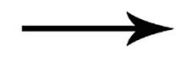

Tannin Release No Borer Activity

\section{Prop Roots}

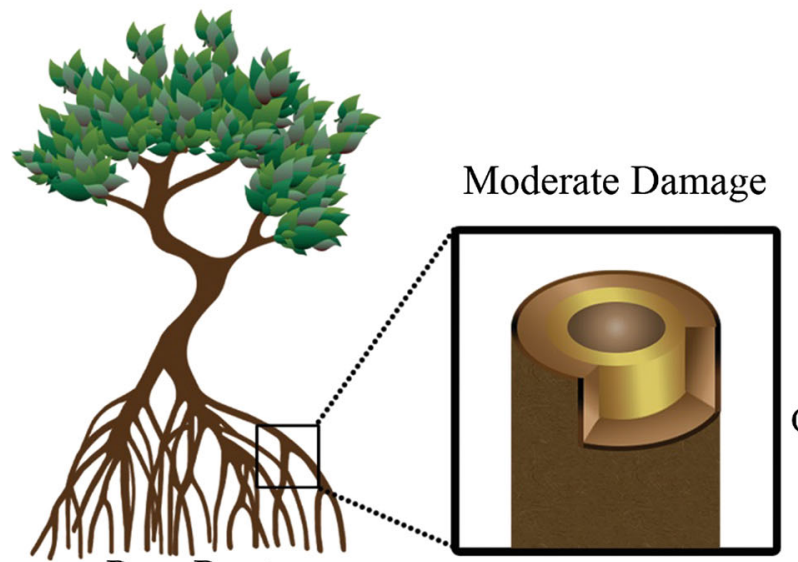

Prop Roots

Tolerance

Mechanism

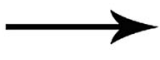

Over Compensation

Limited Borer

Activity
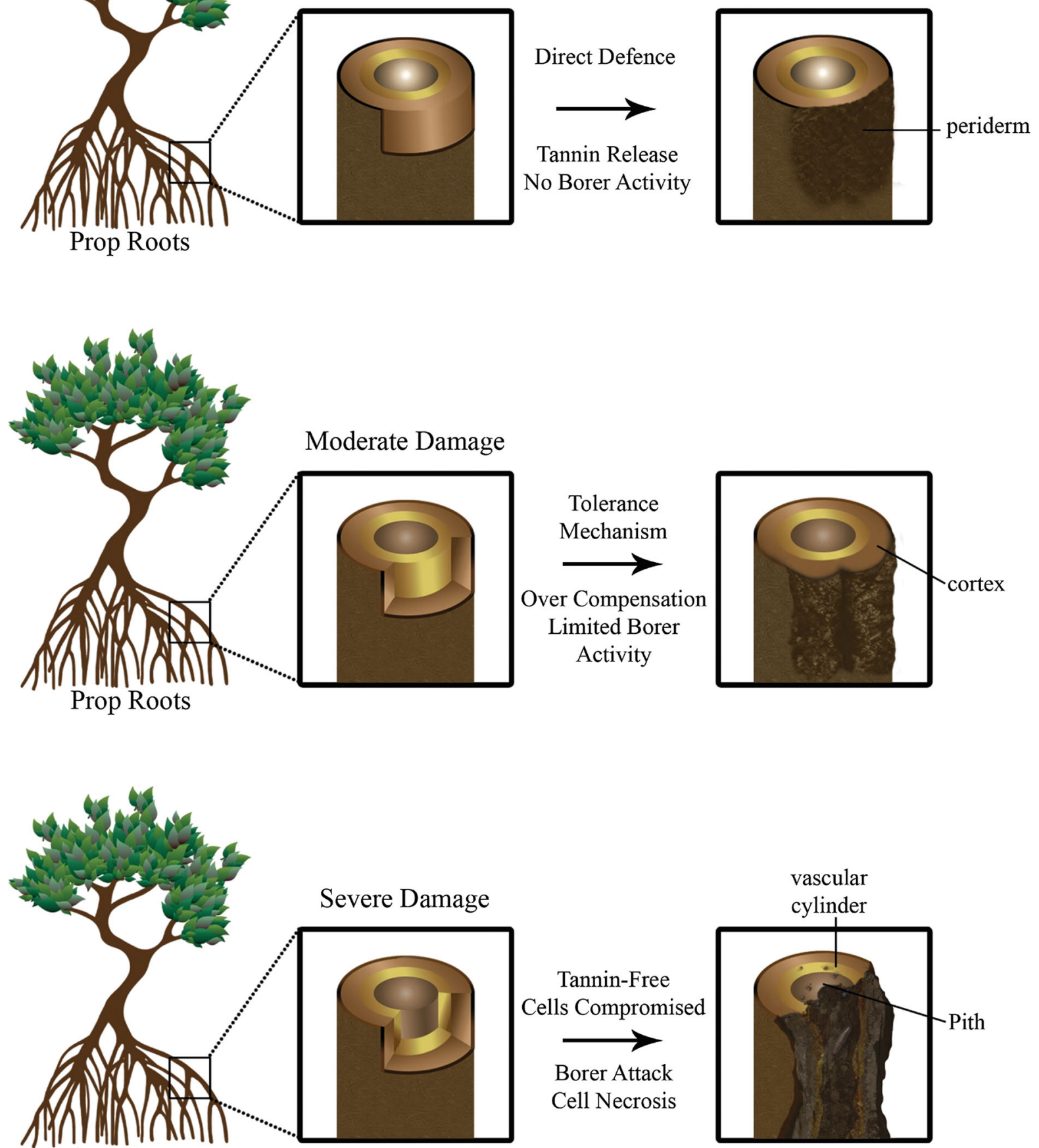

Prop Roots

Tannin-Free

Cells Compromised

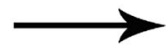

Borer Attack

Cell Necrosis

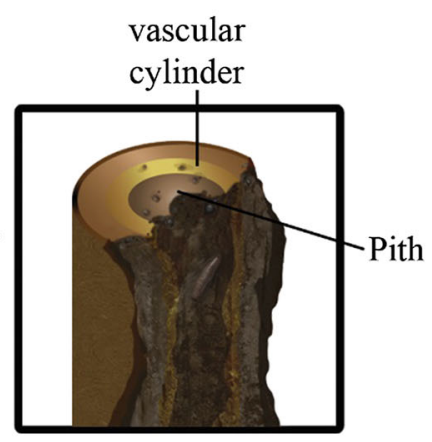


Acknowledgements We are grateful to Operation Wallacea for arranging lodgings and visas. Fieldwork for IWH was supported by Operation Wallacea and field collections of proproot measurements were helped by Kungdan. This study benefited from discussions with Mike $\mathbf{J}$ Swift, and an unpublished study of MJS and SMC. We also extend many thanks to Clare Taubman for creating the summary diagram.

Open Access This article is distributed under the terms of the Creative Commons Attribution 4.0 International License (http:// creativecommons.org/licenses/by/4.0/), which permits unrestricted use, distribution, and reproduction in any medium, provided you give appropriate credit to the original author(s) and the source, provide a link to the Creative Commons license, and indicate if changes were made.

\section{References}

Agrawal, A. A., 1999. Induced responses to herbivory in wild radish: effects on several herbivore and plant fitness. Ecology 80: 1713-1723.

Agrawal, A. A, Strauss, S. Y. \& Stout, M. J. 1999. Costs of reduced responses and tolerance to herbivory in male and female fitness components of wild radish. Evolution 53: 1093-1104.

Alongi, D. M., 1987. The influence of mangrove-derived tannins on intertidal meiobenthos in tropical estuaries. Oecologia 71: 537-540.

Barkati, S. \& N. M. Tirmizi, 1991. The environmental impact of wood-borers in mangrove swamps. Symposia of the Zoological Society of London 63: 251-263.

Bhatt, J. R. \& Kathiresan, K., 2012. Valuation, carbon sequestration potential and restoration of mangrove ecosystems in India. In: Sharing Lessons on Mangrove Restoration, Proceedings and a Call for Action from an MFF Regional Colloquium, pp. 19-38.

Bloch, R., 1952. Wound healing in higher plants II. Botanical Review 18: 655-679.

Borges, L. M. S., S. M. Cragg, J. Bergot, J. R. Williams, B. Shayler \& G. S. Sawyer, 2008. Laboratory screening of tropical hardwoods for natural resistance to the marine borer Limnoria quadripunctata: the role of leachable and non-leachable factors. Holzforschung 62: 99-111.

Brooks, R. A. \& S. S. Bell, 2002. Mangrove response to attack by a root boring isopod: root repair versus architectural modification. Marine Ecology Progress Series 231: 85-90.

Cragg, S. M. \& I. W. Hendy, 2010. Mangrove Forests of the Wakatobi National Park. In Clifton, J., et al. (eds), Marine Research and Conservation in the Coral Triangle. Nova Science Publishers, Hauppauge, NY.

Crow, B. \& J. Carney, 2013. Commercializing nature: mangrove conservation and female oyster collectors in the Gambia. Antipode 45: 275-293.

Davidson, T. M., C. de Rivera \& H.-L. Hsieh, 2014. Damage and alteration of mangroves inhabited by a marine wood-borer. Marine Ecology Progress Series 516: 177-185.

Doorn, W. G. V. \& P. Cruz, 2000. Evidence for a woundinginduced xylem occlusion in stems of cut chrysanthemum flowers. Postharvest Biology and Technology 19: 73-83.
Ellison, A. M. \& E. J. Farnsworth, 1996. Spatial and temporal variability in growth of Rhizophora mangle saplings on coral cays: links with variation in insolation, herbivory, and local sedimentation rate. Journal of Ecology 84: $717-731$.

Feller, I. C., 2002. The role of herbivory by wood-boring insects in mangrove ecosystems in Belize. Oikos 97: 167-176.

Feller, I. C. \& W. N. Mathis, 1997. Primary herbivory by woodboring insects along an architectural gradient of Rhizophora mangle. Biotropica 29: 440-451.

Filho, C. S., C. H. Tagliaro \& C. R. Beasley, 2008. Seasonal abundance of the shipworm Neoteredo reynei (Bivalvia, Teredinidae) in mangrove driftwood from a northern Brazilian beach. Iheringia Series of Zoology 98: 17-23.

Franke, R. \& L. Schreiber, 2007. Suberin - a biopolyester forming apoplastic plant interfaces. Plant Biology 10: 252-259.

Gill, A. M. \& P. B. Tomlinson, 1971. Studies on the growth of red mangrove (Rhizophora mangle L.) 2. Growth and differentiation of aerial roots. Biotropica 3: 63-77.

Gill, A. M. \& P. B. Tomlinson, 1977. Studies on the growth of red mangrove (Rhizophora mangle L.) 4. The adult root system. Biotropica 9: 145-155.

Hanley, M. E., B. B. Lamont, M. M. Fairbanks \& C. M. Rafferty, 2007. Plant structural traits and their role in anti-herbivore defence. Perspectives in Plant Ecology, Evolution and Systematics 8: 157-178.

Haukioja, E. \& J. Koricheva, 2000. Tolerance to herbivory in woody vs. herbaceous plants. Evolutionary Ecology 14: 551-562.

Hendy, I. W., J. Eme, T. F. Dabruzzi, R. V. Nembhard, S. M. Cragg \& W. A. Bennett, 2013. Dartfish use teredinid tunnels in fallen mangrove wood as a low-tide refuge. Marine Ecology Progress Series 486: 237-245.

Hol, G. W., M. Macel, J. A. van Veen \& E. van der Meijden, 2004. Root damage and aboveground herbivory change concentration and composition of pyrrolizidine alkaloids of Senecio jacobaea. Basic and Applied Ecology 5: 253-260.

Jusoff, K., 2013. Malaysian Mangrove Forests and their Significance to the Coastal Marine Environment. Polish Journal of Environtal Studies 22: 979-1005.

Karban, R. \& J. H. Myers, 1989. Induced plant responses to herbivory. Annual Review of Ecology and Systematics 20: 331-348.

Karban, R., A. A. Agrawal \& M. Mangel, 1997. The benefits of induced defences against herbivores. Ecology 78: 1351-1355.

Kimura, M. \& H. Wada, 1989. Tannins in mangrove tree roots and their role in the root environment. Soil Science and Plant Nutrition 35: 101-108.

Kohlmeyer, J., B. Bebout \& B. Volkmann-Kohlmeyer, 1995. Decomposition of mangrove wood by marine fungi and teredinids in Belize. Marine Ecology 16: 27-39.

Lee, S. Y., J. H. Primavera, F. Dahdouh-Guebas \& S. Record, 2014. Ecological role and services of tropical mangrove ecosystems: a reassessment. Global Ecology and Biogeography 23: 726-743.

Lennartsson, T., P. Nilsson \& J. Tuomi, 1998. Induction of overcompensation in the field gentian, Gentianella campestris. Ecology 79: 1061-1072. 
Mattheck, K. \& H. Breloer, 1994. The body language of trees, a handbook for failure analysis. Her Majesty's Stationary Office, London: 24.

McIvor, A. L., Möller, I., Spencer, T., \& Spalding, M., 2013. Mangroves as a sustainable coastal defence. Page 8 in 7 th International Conference on Asian and Pacific Coasts (APAC). The Nature Conservancy, University of Cambridge, and Wetlands International, Bali, Indonesia, September, pp. 24-26.

Nemeth, R., A. Ott, P. Takáts \& M. Bak, 2013. The effect of moisture content and drying temperature on the colour of two poplars and robinia wood. Bioresources 8: 2074-2083.

Paige, K. N., 1992. Overcompensation in response to mammalian herbivory: from mutualistic to antagonistic interactions. Ecology 73: 2076-2085.

Paige, K. N., 1999. Regrowth following ungulate herbivory in Ipomopsis aggregata: geographic evidence for overcompensation. Oecologia 118: 316-323.

Paige, K. N. \& T. G. Whitham, 1987. Overcompensation in response to mammalian herbivory: the advantage of being eaten. The American Naturalist 129: 407-416.

Perry, D. M., 1988. Effects of associated fauna on growth and productivity in the red mangrove. Ecology 69: 1064-1075.

Ribi, G., 1982. Differential colonization of roots of Rhizophora mangle by the woodboring isopod Sphaeroma terebrans as a mechanism to increase root density. Marine Ecology 3: 13-19.

Rimmer, M. A., S. L. Battaglene \& P. L. Dostine, 1983. Observations on the Distribution of Bankia australis Calman (Mollusca: Teredinidae) in the Patonga Creek Mangrove Swamp, New South Wales. Australian Journal of Marine and Freshwater Research 34: 355-357.

Robertson, A. I., 1990. Plant-animal interactions and the structure and function of mangrove forest ecosystems. Australian Journal of Ecology 16: 433-443.

Robertson, A. I. \& P. A. Daniel, 1989. Decomposition and the annual flux of detritus from fallen timber in tropical mangrove forests. Limnology and Oceanography 34: 640-646.
Roonwal, M. L., 1954. The marine borer, Bactronophorus thoracities (Gould) [Mollusca, Eulamellibranchiata, Teredinidae], as a pest of living trees in the mangrove forests of the Sunderbans, Bengal, India. Proceedings of the. Zoological Society 7: 91-103.

Sedghi, M., A. Golian, P. Soleimani-Roodi, A. Ahmadi \& M. Aami-Azghadi, 2012. Relationship between color and tannin content in sorghum grain: application of image analysis and artificial neural network. Revista Brasileira de Ciência Avícola 14: 57-62.

Shigo, A. L., 1985. Compartmentalization of decay in trees. Scietific American 252: 96-103.

Strauss, S. Y. \& A. A. Agrawal, 1999. The ecology and evolution of plant tolerance to herbivory. Tree 14: 179-185.

Suh, S. S., J. Hwang, M. Park, H. S. Park \& T. K. Lee, 2014. Phenol content, antioxidant and tyrosinase inhibitory activity of mangrove plants in Micronesia. Asian Pacific Journal of Tropical Disease 7: 531-535.

Svavarsson, J., M. K. Osore \& E. Olafsson, 2002. Does the wood-borer Sphaeroma terebrans (Crustacea) shape the distribution of the mangrove Rhizophora mucronata?. Ambio 31: 574-579.

Tomascik, T., Mah, A. J., Nontji, A., \& Moosa, M. K., 1997. The Ecology of the Indonesian Seas Part Two. The ecology of Indonesia series, volume VIII. Periplus Editions, Singapore.

Turner, R. D., 1976. Some factors involved in the settlement and metamorphosis of marine bivalve larvae. In Sharpley, J. M. \& A. M. Kaplan (eds), Proceedings of the 3rd International Biodegradation Symposium. Applied Science, Barkin, UK, pp. 409-416.

Wier, A. M., M. A. Schnitzler, T. A. Tattar, E. J. Klewkowski \& A. I. Stern, 1996. Wound periderm development in red mangrove, Rhizophora mangle L. International Journal of Plant Science 157: 63-70. 